IZA DP No. 7336

Job Search Channels, Neighborhood Effects and Wages Inequality in Developing Countries:

The Colombian Case

Gustavo Adolfo García

Catia Nicodemo

April 2013 


\title{
Job Search Channels, Neighborhood Effects and Wages Inequality in Developing Countries: The Colombian Case
}

\author{
Gustavo Adolfo García \\ Universitat Autònoma de Barcelona \\ Catia Nicodemo \\ Oxford University \\ and IZA
}

Discussion Paper No. 7336

April 2013

IZA
P.O. Box 7240
53072 Bonn
Germany

Phone: +49-228-3894-0

Fax: +49-228-3894-180

E-mail: iza@iza.org

Any opinions expressed here are those of the author(s) and not those of IZA. Research published in this series may include views on policy, but the institute itself takes no institutional policy positions. The IZA research network is committed to the IZA Guiding Principles of Research Integrity.

The Institute for the Study of Labor (IZA) in Bonn is a local and virtual international research center and a place of communication between science, politics and business. IZA is an independent nonprofit organization supported by Deutsche Post Foundation. The center is associated with the University of Bonn and offers a stimulating research environment through its international network, workshops and conferences, data service, project support, research visits and doctoral program. IZA engages in (i) original and internationally competitive research in all fields of labor economics, (ii) development of policy concepts, and (iii) dissemination of research results and concepts to the interested public.

IZA Discussion Papers often represent preliminary work and are circulated to encourage discussion. Citation of such a paper should account for its provisional character. A revised version may be available directly from the author. 


\section{ABSTRACT \\ Job Search Channels, Neighborhood Effects and Wages Inequality in Developing Countries: The Colombian Case*}

This paper analyses the relationship between social networks and the job search behaviour of individuals. Networking is not only based on friends and relatives but also on neighbourhood. The geographic closeness is associated to social interactions. Individuals who are in physical and social proximity share the same sources of information, because they divide individual characteristics or because they learn from one another's behaviour. Using data from Colombia in 2009 we explore how neighbourhoods have an effect on the channel used to search for a job (formal vs informal). People tend to opt for a formal or informal channel depending on the channel selected by employed people in their neighbourhood. In addition, we study the wage premium in using a formal or informal channel, exploring the inequality that can arise using a different job search method. Our results show that the neighbourhood affects the individual's job search method and referral workers earn less wage at the bottom of the wage distribution with respect to non-referred workers. At the top of the wage distribution the difference observed is due to different characteristics between the two groups. Colombia presents persistent high levels of informality and inequality. These features impose important social and economic costs such as low tax collection, low employee protection and deficiencies in the labour intermediation process with strong informational asymmetries in the job search. New policies to regulate the labour market are need.

JEL Classification: $\quad \mathrm{J} 64, \mathrm{~J} 31, \mathrm{~J} 24, \mathrm{P} 23, \mathrm{J6}, \mathrm{J} 7$

Keywords: job search, formal and informal networks, neighborhood effects, quantile regression

Corresponding author:

Catia Nicodemo

Department of Economics

Oxford University

Nuffield College

New Road, OX4 1NF, Oxford

United Kingdom

E-mail: catia.nicodemo@economics.ox.ac.uk

\footnotetext{
* Financial support from the Fundacion Ramon Areces (Ayuda Investigacion 2010) is gratefully acknowledged.
} 


\section{Introduction}

Networking has increasingly become important not only in gaining friends but also for job search. Social networks are an important source of information in the labour market and many workers find jobs through friends and relatives. People that search for a job have several options to find it: read newspapers, go to employment agencies, browse the web and mobilise their local networks of friends and relatives. Empirical evidences indeed suggest that about half of all jobs are found through contacts. Holzer (1988) shows that among 16-23 years old workers who reported job acceptance, $66 \%$ used informal search channels. More evidence also is reported by a recent study by Franzen and Hangartner (2006), around $44 \%$ of the workers in the U.S. and $34 \%$ of the workers in Germany have found their jobs through social networks. Individuals tend to use several sources of information during the job search, and the literature has paid particular attention to the choice of search channels and its impact on labor market outcomes (see e.g. Holzer, 1988; Van den Berg and Van der Klaauw, 2006; Weber and Mahringer, 2008).

In particular, research distinguishes between two different search channels: formal and informal. Formal channels are defined as search by newspaper advertisements, internet, public employment office, etc., while informal refers to search via friends and relatives.

An extensive literature analyses the effect of networks and informal search on labour market outcomes. One of the most important assumptions is that informal job contacts reduce informational asymmetry and this is translated in terms of labour market outcomes to higher wages and high job duration (Montogomery, 1991, Calvo-Armegol and Jackson, 2004, Bentolila et al., 2010). However, the empirical evidence is rather mixed. It has been found that informal search channels can be associated with a premium as well as with a penalty in terms of wages and employment stability (see Ioannides and Datcher Loury, 2004).

In this paper, we propose a new empirical strategy for identifying network effects on the job search channel and labour market outcomes. We focus on the neighbourhood effects, estimating the probability to find a job trough a informal and formal channel, looking at the characteristics of the neighbourhood. We also account the effects of the use of formal or informal channels on wages.

We show that the chance to get a job trough one channel (formal or informal) increases with the type of neighbourhood. The geographic closeness is associated to social interactions. Individuals who are in physical and social proximity share the same sources of information because they share individual characteristics or because they learn from one another's behaviour (Manski, 2000), so that each worker has the same information by people around him. Elliott (1999) finds that those in high-poverty neighbourhoods were substantially more likely to use informal job-search methods than those from low-poverty 
neighbourhoods, because they share the same information. Topa (2001) finds geographic correlations in patterns of unemployment across neighbourhoods and cites them as evidence of positive correlation between employment and wages of networked individuals. He finds that high unemployment rates were concentrated in relatively few areas of Chicago in 1980 and 1990. Conley and Topa (2003) find that socioeconomic characteristics (and in particular ethnic and occupational distance) explain a substantial component of the spatial dependence in unemployment.

Using the Great Integrated Household Survey (GIHS) in 2009 for Colombia, which is a national survey that has information at individual level on labour force of twenty-three major cities and their metropolitan areas in Colombia, we find that the search channel is influenced by the way that the neighbours found their current employment. Individuals that live close to others and find a job by a formal network have more probability to use the same channel. We also find a significantly positive effects of channel on wage distribution. Inequality increase across people that use informal channels, especially at the bottom of the wage distribution. From a policy point of view, to avoid this inequality, the Colombian Government needs to take more actions to keep away spatial segregation across people.

Colombia represents an ideal case to analyze the job search behaviour of individuals. Colombia is a medium-income nation characterised by a moderate but stable economic growth accompanied by high levels of poverty, inequality and violence (Royuela and García, 2013). As in other developing country regions, the labour market of Colombia presents persistent high levels of informality and inequality. These features impose important social and economic costs such as low tax collection, low employee protection and deficiencies in the labour intermediation process with strong informational asymmetries in the job search.

Most of the existing literature on social networks is related to developed countries. Scarce is the evidence in developing countries of the importance of social networks in finding a job and the effects on labour market outcomes (see for example Banerjee and Bucci (1995), Munshi (2003) and Wahba and Zenou (2005)). In a Latin American context, specifically for Colombia, the only work is by Diaz (2012), who finds that individuals who used informal channels were more likely to be employed and earn lower wages than individuals using other job search strategies for the year 2002. However, this study does not account for the network neighbourhood, or inequality across workers that have found a job trough different channels.

The purpose of this study is to give new evidences in the context of a developing country on network and job search considering the behaviour of neighbours, and whether there is a wage premium or not in find with formal or informal contacts a job. To the best of our knowledgement this is the first paper that studies the relation between 
neighbourhoods and the probability to find a formal or informal job.

The remainder of the paper is as follows: section 2 describes the model; section 3 presents the data used in the study; empirical methods and results are reported in Section 4 ; finally, section 5 is devoted to the discussion of results and conclusions.

\section{The Model}

In order to analyse the interaction among neighbourhoods on the labour market and the probability to use a formal or informal channel to find a job, we propose a model in which each individual can share information about job opportunities with his social contacts, and employed people have more possibilities to transmit more information. Given that, the probability to find a job trough a formal channel is greater if higher is the employment rate of neighbourhood that have found the job with the same method.

We assume there are only two channels to find a job, formal $f$ and informal inf. For each individual the probability to find a job trough one of this channels depends on a set of owner characteristics $X$ but also on the information $I_{i}$ that residents in block $i$ share with him. In particular, the information received by residents in block $i$ is an increasing function of the employment rate in the neighbourhood by the type of channel used to find their job:

$$
I_{i}=N_{f} /\left(N_{f}+N_{i n f}\right)
$$

Where $N_{f}$ and $N_{\text {inf }}$ represent the people in block $i$ that have found a job through the formal and informal Channel respectively. Under this assumption, we can calculate the probability that an individual uses a channel instead of other as:

$$
\operatorname{Prob}\left(C_{j i}\right)=\gamma+X_{j i} \beta_{j i}+\theta I_{i}+u_{j}
$$

Where the $C_{j}$ is equal to 1 if the individual chooses a formal channel and zero otherwise. This probability depends on a set of individual characteristics $\left(X_{j i}\right)$ such as age, education..., and the ratio $I_{i}$ of people that have found the job by formal channel.

After observing which channel the individual has used to find the job, we account for a model to examine the difference in wage among individuals that use different channels. We split the job candidates into two groups: the referrals $\left(k_{R}\right)$ and the non referrals $\left(k_{N R}\right)$. We define a referral as any worker that has been recruited through a formal channel.

The total number of workers are Poisson-distributed with (large) mean $k_{R}$ and $k_{N R}$ for referrals and not, respectively.

We have two possibilities of recruiting: by referral or formal (just considering the curriculum). Following the model of Lang et al. (2005, 2010) and Lang and Manove 
(2003), we begin by assuming that workers and firms meet randomly. The firm does not know ex ante the productivity of their candidate, so managers make a rank of preferences considering first candidates with referrals, because this gives them a signal of productivity. We assume that firms will make positive or null profits (but not negative profits) when hiring someone for that position and only one meeting can take place in each period. Given these assumptions the expected number of referrals is:

$$
k_{R}=p(w) k_{R}
$$

and for the non referral candidate is:

$$
k_{N R}=p(w) k_{N R}
$$

Then, the probability of hiring a referral or formal candidate would be respectively:

$$
\begin{gathered}
P_{R}=\frac{1-e^{-k_{R}}}{k_{R}} \\
P_{N R}=e^{-k_{R}} \frac{1-e^{-k_{N R}}}{k_{N R}} .
\end{gathered}
$$

This means that formal workers would be hired just in case a referral does not apply for an open vacancy, see Manove and Lang (2003) for more details.

The expected wage paid for referral workers is:

$$
W_{w R}=W \frac{1-e^{-k_{R}}}{k_{R}}
$$

While for formal workers is

$$
W_{w R}=W e^{-k_{R}} \frac{1-e^{-k_{N R}}}{k_{N R}} .
$$

The wage of formal workers is higher than that of referral workers if $\frac{1-e^{-k_{N R}}}{k_{N R}}>\frac{1-e^{-k_{R}}}{k_{R}}$. This implies that most workers are being hired with referral and that the network among referrals is big. However, in Colombia we do not find this evidence, as we explain in the empirical section, one possible explanation is due to that the two types of workers suffer some segregation into labour market by firms or sectors.

In Section 3 we explain the empirical strategy followed to estimate the probability to find a job trough a formal channel and the difference across wage distribution between formal and informal channels. 


\section{Data Description}

As a developing country, Colombia presents a low quality of its institutional environment and a marked heterogeneity in its labour market. The absence of an unemployment insurance system, the poor performance of public job search programs and a high informal employment level (ILO, 2011) impose important differences in the nature and impact of the job search process.

The data used in this paper come from the Great Integrated Household Survey (GIHS) for 2009, carried out by the National Administrative Statistics Department (DANE). This cross-section survey has information at individual level on labour force of twenty-three major cities with their metropolitan areas in Colombia. 1. This survey gathers information about the employment condition of people (whether they work, what they do, how much they earn, whether they have social security for health care, or whether they are looking for a job), as well as about the general characteristics of the population, such as sex, age, marital status, educational level, sources of income and expenses.

The sample considered in this work is composed of employees between 16 and 65 years old who have found their jobs in the last year.2 our final sample consists of 42179 observations. 3

Our variable of interest is the channel used to find the job. In the survey, workers are asked to indicate how they have found their current job. There are seven possible job search channels from which only one can be chosen:

1. through family, friends or other contacts;

2. by applying to the employer directly;

3. by applying to employment agencies or intermediaries;

4. by inserting or answering adverts in newspapers;

5 . by applying to selection processes by convening, usually government enterprises;

6. through the information system of the SENA 4 ;

7. other.

These seven alternatives have been regrouped to define two main search job channels: formal and informal. In the first channel (formal) we regard alternatives 3, 4, 5 and 6, while in the second channel we include alternatives 1, 2 and 7 . Usually, this classification

\footnotetext{
${ }^{1}$ Namely, Medellín, Barranquilla, Bogotá Cartagena, Tunja, Manizales, Florencia, Popayan, Valledupar, Montería, Quibdó, Neiva, Rioacha, Santa Marta, Villavicencio, Pasto, Cúcuta, Armenia, Pereira, Bucaramanga, Sincelejo, Ibagué and Cali.

${ }^{2}$ This restriction is necessary to avoid problems of bias because we do not have information about the movements across years.

${ }^{3}$ Notice that all employers and self-employed are excluded here.

${ }^{4}$ SENA (Servicio Nacional de Aprendizaje), which is a national public institution that offers courses in technical and vocational training to workers. This institution has an information system which connects the unemployed with the vacancies generated by entrepreneurs. This service is free for both employees and employers.
} 
is used by the major literature related to job search methods (see Holzer, 1988).

Another main variable we have built is the variable relative to neighbourhood, as a factor that has an influence on the job search. Typically, the empirical literature on social networks defines a network according to a geographic or cultural proximity to a group of individuals. In this paper we use physical proximity among individuals as a measure of social network. Specifically, we measure the social interactions on job search that operate at the level of the residential neighbourhood. The underlying idea is that agents exchange information about job opportunities more frequently with people who live physically close. The neighbourhood effects variable is defined as the ratio of the number of individuals who live in the same block $i$ and have found a job through a formal channel in a common economic sector $s\left(N\right.$ formal $\left._{i s}\right)$ to the total number of individuals in the same block and sector $\left(N_{i s}\right)$ :

$$
\text { Neighborhood effects }{ }_{i s}=\frac{N \text { formal }_{i s}}{N_{i s}}
$$

The first evidence among job networks and neighbourhood can be found in Figure 1, where we report nodes at city block level for Bogota city, and distinguish between residents that have found previous jobs trough formal and informal channels in two different years (2006 and 2009) $!^{5}$ As we can see, workers that use formal channels are very close to each other and they increase across years in the neighbourhood where other workers have previously used the same channel.

Table 1 depicts some descriptive statistics among variables used in this study, for all samples and separately for types of channel. We can see how workers prefer to use informal networks to find a job. This prevalence is due to the fact that the Colombian labour market is not sufficiently institutionalized, which could indicate that there are significant deficiencies in the labour intermediation process. Looking at the two groups we observe that the average wage for formal channels is higher than that for informal channels. Regarding human capital and personal characteristics we can see that workers who use formal channels to find their job are, on average, three years younger and more educated than those who use informal networks. Jobs found through formal channels present a higher percentage of individuals with tertiary education (52\%), while jobs found through informal channels are preferred by individuals with primary and secondary education $(71 \%)$. There are not differences by gender, dependent kids or marital status between the two channels.

Looking at the characteristics of employment we can see that jobs found using personal contacts are jobs with less qualification, $61 \%$ (blue collar), while $56 \%$ of workers that have used formal networks are managers or white collar. Jobs found through formal or informal

\footnotetext{
${ }^{5}$ The scale of city block in Colombia is comparable to that used in the US Census.
} 
channels appear to be generally concentrated in the private sector. A significant difference between the two groups is found in the size of the firm: big firms prefer hire using formal channels. Finally, data shows that $21 \%$ of workers of formal channels are employed in the industrial sector, there is a similar percentage for jobs in the public administration, followed by jobs in the commerce sector (17\%). While, the use of informal channels leads most likely to jobs in the service $(23 \%)$ and commerce sector $(21 \%)$.

In the next section we estimate the probability to use one channel instead of another and the inequality on wage distribution between formal and informal channels.

\section{Empirical Model and Results}

\subsection{Social interactions on job search channels}

This section describes the methodologies used in the empirical analysis. We present evidence on the empirical effect of job search method on both labour outcomes: the probability of being employed, considering the neighbourhood network and the hourly wages.

The first relevant outcome is the channel used to find the job, a binary variable equal to one if individual $j$ has found the employment through a formal channel.

The results are depicted in Table 2 using three different specifications: M1, where we do not use any control; M2, where we include the industry, occupation and firm size as controls; and M3 which includes M2 plus the city controls to capture any unobservable region effects. The neighbourhood effects are positive in all specifications. The way neighbours find their employment affects the individual's own job search. When we control for job characteristics, firm size dummies, city dummies, occupation and industry dummies as additional explanatory variables, a higher proportion of neighbours who have found a job by a formal channel increases the probability of using formal channels by 8.4 percentage points.

Regarding the demographic characteristics variables used as controls, we find that education has a positive relationship with the use of formal networks to find a job, in particular at high education levels. This result demonstrates that individuals with a high level of qualification usually do not seek a job through informal channels and/or firms do not use informal channels to fill high-skilled positions. Therefore, an individual with tertiary education increases the likelihood of using an formal job search channel by 3.6 percentage points. Age has a negative effect on the probability of using formal networks. This may reflect the fact that older workers are less likely to actively search a job. Finally, the variable related to the type of employment indicates that workers in the private sector are more probable to search jobs through informal channels. 
These findings are a new evidence on the social interactions for search a job at neighbourhood level.

\subsection{Wage analysis between channels}

The question we answer in this subsection is if jobs created by formal channels are better or worse than those created by informal channels. In the literature the results still remain controversial. Some researchers argue that the use of informal referrals in the job search process leads to higher wages due to an improvement of the quality of the job match, because potential employers and job seekers have access to better and more reliable sources of information (Montgomery, 1991; Mortensen and Vishwanath, 1994; Simon and Warner, 1992). In contrast, there are some theories that postulate a negative relationship between the use of informal referrals and wages, for example due to the fact that job seekers are willing to sacrifice higher wages to obtain a position rapidly (Bentolila et al., 2010).

To address this point we first estimate the Kernel density of the logarithm of the wage between the formal and the informal channel (see Figure 2). For both groups, the wage is concentrated around the mean, however the formal channel presents a swift on the left. People that enter with formal channel have better wage at the top of the distribution, while at the bottom both groups are equally distributed.

To control for other variables that can affect the wage we estimate a percentile regression by channel. The results, shown in Table 3, are quite different not only between channels but also between percentiles. Age affects positively the wage for both groups, however at high percentiles the value is bigger. Education, especially tertiary, increases the wage in informal and formal channels, but it has not effect on formal at the 20th percentile. Male and marital status have a positive effect on wage, but are not significant at the bottom and at the top for the formal channel. Dependent kids affect negatively the wage for workers with informal job search, such as the private sector. Same results can we have for formal channel after the 20th percentile.

Workers that use informal networks may be non randomly selected, they are more likely to use informal channel due, for example, to their abilities or skills, which are not observed. Although Diaz (2010), with several estimations, excludes this type of selection between formal and informal channels in Colombia, we estimate a quantile wage distribution model that allow us to look at the effects of the channels, distinguish between the difference due to observable characteristics and not among workers wage's.

Koenker-Basset (1978) proposed a complete new and different method of calculating the quantile regression. It can be estimated by minimizing $\beta(\tau)$ the following expression:

$$
\widehat{\beta}(\tau)=\min n^{-1}\left[\sum_{i}^{n} \rho_{\tau}\left(Y_{i}-X_{i} \beta\right)\right],(i=1, \ldots . n),
$$


with the check function $\rho_{\tau}$ weighting the residuals $\mu_{i}$ asymmetrically:

$$
\rho_{\tau}\left(\mu_{i}\right)= \begin{cases}\tau \mu_{i} & \text { if } \mu_{i} \geq 0 \\ (\tau-1) \mu_{i} & \text { if } \mu_{i}<0\end{cases}
$$

Starting from the study of Koenker-Basset (1978), Machado and Mata (M-M) in 2005 proposed a method to extend the traditional Oaxaca-Blinder decomposition based on the quantile regression. Considering two groups, 0 and 1, whose stochastic characteristics for each group are $X_{0}$ and $X_{1}$, the regression quantile can be written for each group as:

$$
Q_{y}(Y \mid X)=X_{i} \beta(\tau) \quad \forall \tau, i \in(0,1)
$$

where $Y \mid X$ is the conditional quantile. M-M propose an estimation of the counterfactual unconditional wage distribution, generate a random sample of size $m$ from a uniform distribution $U[0,1]$, and then calculate the conditional quantile regression for each group. They simulate the wage distribution of the second group on the basis of the wage distribution and the characteristics of the first group, and repeat these steps $m$ times.

The difference of the unconditional quantiles between the two groups can be decomposed as:

$\widehat{F}_{Y 1}^{-1}(\theta \mid T=1)-\widehat{F}_{Y 0}^{-1}(\theta \mid T=0)=\underbrace{\widehat{F}_{Y 1}^{-1}(\theta \mid T=1)-\widehat{F}_{Y 1}^{-1}(\theta \mid T=0)}_{\text {Characteristics }}+\underbrace{\widehat{F}_{Y 1}^{-1}(\theta \mid T=0)-\widehat{F}_{Y 0}^{-1}(\theta \mid T=0)}_{\text {Coefficients }}$

where $\widehat{F_{Y t}^{-1}}(\theta \mid T=t)$ denotes the $\theta^{\text {th }}$ quantile of wage $Y$ for groups $t$ 's while $\widehat{F}_{Y 1}^{-1}(\theta \mid T=0)$ is the counterfactual unconditional wage distribution.

In Figures 3, we present Machado and Mata model of wage decomposition by channel used to seek a job. In this Figure we portrait the decomposition of the wage in coefficients and characteristics. In addition, we also show the overall and interval of confidence of the coefficients. We can observe that the wage gap between formal and informal channel is positive. Part of this gap is due to the difference in the coefficients (unobservable), especially at the bottom of the distribution. One possible explanation comes from the fact that jobs found through informal referrals are obtained more quickly but also with lower wages. Another possible explanation is that referred workers are segregated into types of jobs with respect to no referred. Instead, looking at the top of the wage distribution, the wage gap between the two channels is due to different characteristics between individuals that use formal and informal channels. The returns on formal channels are quite huge with respect to the informal ones. 


\section{Conclusion}

This paper carries out a first evidence about the relationship between social networks, the neighbourhood effect and the job search. Networking is not based just only on friends and relatives, but physical and social proximity are also important to influence the individuals behaviour. Information about jobs can be derived by people that are employed and live close to job seekers. Using data from Colombia we explore how the neighbourhood has an effect on the channel used to search a job. In addition, in this research we analyse the distribution of the wage between referred and non referred workers, distinguishing the wage gap between the two groups in difference due to characteristics and to unobservable.

Our results confirm the theory that proximity is a social interaction and has an influence on job search methods. People tend to use a formal or informal channel influenced by their neighbours' choice. Moreover, informal channels are more used by workers who find low occupations and in small firms. Big firms prefer to hire by no referral.

We also test the presence or not of a wage premium for workers referred and not. The wage distribution across people who have used a formal or an informal channel presents differences at the bottom of the wage distribution with a disadvantage for the latter. This differences are due to unobservable effects, such as poor matching or segregation in some kind of jobs, while at the top of the wage distribution the difference between the two groups is due to the different characteristics among them. It would be interesting to extend this analysis in a longitudinal way and follow the workers to also look at the duration or their carrier, however at the moment this is not possible because Colombia does not have such kind of database.

This study shed light on the mechanisms of social networks and labour outcomes in Colombia, a developing country where the labour market is highly informal, and where the Government needs to address policies to better regulate the labour market and avoid inequality across workers. 


\section{References}

Banerjee, B. (1981). Ruralurban Migration and Family Ties: An Analysis of Family Considerations in Migration Behavior in India, Oxford Bulletin of Economics and Statistics 43(4): 321355 .

Banerjee, B. (1983). Social Networks in the Migration Process: Empirical Evidence on Chain Migration in India, Journal of Developing Areas 17(2): 185196.

Banerjee, B. and G. Bucci (1995). On-the-job Search in a Developing Country: An Analysis Based on Indian Data on Migrants, Economic Development and Cultural Change, 43(3): 565-583

Bentolila, Samuel, Claudio Michelacci, and Javier Suarez. 2010. Social Contacts and Occupational Choice. Economica 77: 20-45.

Conley, T. and G. Topa. (2003). Socio-Economic Distance and Spatial Patterns in Unemployment, Journal of Applied Econometrics, 17(4): 303-327.

Diaz, A. (2012). Informal Referrals, Employment, and Wages: Seeking Causal Directions, Labour, 26(1): 1-30.

Elliott, J. (1999). Social Isolation and Labor Market Isolation: Network and Neighborhood Effects on Less-Educated Urban Workers, The Sociological Quarterly, 40(2): $199-216$

Franzen, A., and D. Hangartner (2006). Social Networks and Labour Market Outcomes: The Non-Monetary Benefits of Social Capital, European Sociological Review, 22(4): 353-368.

Holzer, H. (1988). Job Search Methods Used by Unemployed Youth, Journal of Labor Economics, 1(6): 1-20.

ILO (2011). 2011 Labour Overview. Latin America and the Caribbean, Lima.

Ioannides, Yannis M., and Linda Datcher Loury. 2004. Job Information Networks, Neighborhood Effects, and Inequality, Journal of Economic Literature 42/4:1056-1093.

Koenker, R., and G. Bassett (1978). Regression Quantiles, Econometrica, 46(1): 3350.

Lang K., Lehmann J.Y.K. (2010):Racial discrimination in the Labor Market: Theory and Empirics, Journal of Economic Literature.

Lang K., M. Manove (2003): "Wage Announcements with a Continuum of Workers Types", Annales d'Economie et Statistique, vol. 71-72, pp. 223-244.

Lang K., M. Manove, W. Dickens (2005): "Racial discrimination in Labor Markets with Posted Wage Offers", American Economic Review, vol. 95(4), pp.1327 -1340.

Machado, J., and J. Mata (2005). Counterfactual Decomposition of Changes in Wage Distributions Using Quantile Regression, Journal of Applied Econometrics, 20(4): 445465. 
Manski, C. F. (2000). Economic Analysis of Social Interactions, The Journal of Economic Perspectives, 14(3): 115-136.

Mazumdar, D (1987). Ruralurban Migration in Developing Countries. In: Mills, E. (Ed.), Handbook of Regional and Urban Economics, vol. 2. North-Holland, Amsterdam, pp. 10971128.

Munshi, K., 2003. Networks in the modern economy: Mexican migrants in the US labor market. QuarterlyJournal of Economics 118(2), 549599.

Royuela, V. and García, G.A. 2013. Economic and Social Convergence in Colombia. Regional Studies, http://dx.doi.org/10.1080/00343404.2012.762086

Topa, G. (2001). Social Interactions, Local Spillovers and Unemployment, Review of Economic Studies, 68(2): 261-295.

Van den Berg, G. J., and B. Van der Klaauw (2006). Counselling and Monitoring of Unemployed Workers: Theory and Evidence form a controlled Social Experiment, International Economic Review, 47(3): 895-936.

Wahba, J. and Y. Zenou (2005). Density, Social Networks and Job Search Methods: Theory and Application to Egypt, Journal of Development Economics, 78: 443-473.

Weber, A., and H. Mahringer (2008). Choice and Success of Job Search Methods, Empirical Economics, 35(1): 153-178.

Addison, John T., and Pedro Portugal. 2001. Job Search Methods and Outcomes, IZA DP 349.

Antonovics, Kate, and Robert Town. 2004. Are All the Good Men Married? Uncovering the Sources of the Marital Wage Premium, The American Economic Review 94/2: 317-321.

Ashwin, Sarah, and Valery Yakubovich. 2005. Cherchez la Femme: Women as Supporting Actors in the Russian Labour Market. European Sociological Review, 21/2: 149-163.

Barron, John M., John Bishop, and William C. Dunkelberg. 1985. Employer Search: The Interviewing and Hiring of New Employees. Review of Economics and Statistics 67: 4352 .

Berardi, Nicoletta. 2009. The Remains of Informality in the Formal Sector: Social Networks and Wages in Senegals Labor Market, Toulouse School of Economics WP 129.

Booth, Alison L., and Patrick J. Nolen. 2012. Gender Differences in Risk Behaviour: Does Nurture Matter? The Economic Journal, 122: 5678.

Borghans, Lex, Bart H.H. Golsteyn, James J. Heckman, and Huub Meijers. 2009. Gender Differences in Risk Aversion and Ambiguity Aversion, IZA DP 3985.

Campbell, Karen E., Peter V. Marsden and Jeanne S. Hurlbert. 1986. Social resources and socioeconomic status, Social Networks 8/1: 97-117. 
Carroll, Marylin, Mick Marchington, Jill. Earnshaw, and Stephen Taylor. 1999. Recruitment in Small Firms: Processes, Methods, and Problems. Employee Relations 21/3: 236-250.

Clarke, Simon. 2000. The Closure of the Russian Labor Market, European Societies 2/4: 483-504. Coleman, James S. 1988. Social Capital in the Creation of Human Capital, The American Journal of Sociology 94: 95-120.

Datcher, Linda. 1983. The Impact of Informal Networks on Quit Behavior, Review of Economics and Statistics, 65/3: 491-495.

Gerber, Theodore P., and Olga Mayorova. 2006. Getting Personal: Networks and Stratification in the Russian Labor Market, 1985-2001, accessed online at http://www.hse.ru/data/522/973/1224/2007-10-09Job.pdf

Granovetter, Mark S. 1973. The Strength of Weak Ties. The American Journal of Sociology 78/6: 1360-1380.

Greene, William. 2006. A General Approach to Incorporating Selectivity in a Mode; Note, New York University

Judge, Timothy A., Carl J. Thoresen, Joyce E. Bono, and Gregory K. Patton. 2001. The Job Satisfaction-Job Performance Relationship: A Qualitative and Quantitative Review, Psychological Bulletin 127/3: 376- 407

Kalleberg, Arne L., David Knoke, Peter V. Marsden, and Joe L. Spaeth. 1996. Organizations in America: Analyzing Their Strzuctures and Human Resource Practices. Thousand Oaks, Calif.: Sage Publications.

Kugler, Adriana D. 2003. Employee referrals and efficiency wages, Labour Economics 10: 531556 .

Kupets, Olga. 2005. What is Behind Stagnant Unemployment in Ukraine: the Role of Informal Sector, IZA DP 1738.

ILO (2011). 2011 Labour Overview. Latin America and the Caribbean, Lima.

Ioannides, Y. M., and L. Datcher Loury (2004). Job Information Networks, Neighborhood Effects, and Inequality, Journal of Economic Literature, 42(4): 1056-1093.

Labini, Mauro Sylos. 2005. Social Networks and Wages: It is All About Connections!, LEM WP Series 2004/10.

Larsen, Anna Folke, and Nina Torm. 2009. Social Networks and Wage outcomes in Vietnam, accessed at http://www.econ.ku.dk/torm/Papers/Larsen

Lehmann, Hartmut, Norberto Pignatti, and Jonathan Wadsworth. 2006. The Incidence and Cost of Job Loss in the Ukrainian Labor Market, Journal of Comparative Economics 34/2: 248-271.

Lin, Nan. 1999. Social Networks and Status Attainment, Annual Review of Sociology 25: 467-487 Machado, J., and J. Mata (2005). Counterfactual Decomposition of Changes in Wage Distributions Using Quantile Regression, Journal of Applied Econometrics, 20(4): 
445-465.

Marsden, Peter V. 1994. The Hiring Process. Recruitment Methods. American Behavioral Scientist. 37/7: 97991.

Marsden, Peter V., and Karen E. Campbell. 1990. Recruitment and Selection Processes: The Organizational Side of Job Search. pp. 59-79 in Social Mobility and Social Structure, edited by Ronald L. Breiger. New York: Cambridge University Press.

Marsden, Peter V., and Elizabeth H. Gorman. 2001. Social Networks, Job Changes, and Recruitment, in I. Berg and A. L. Kalleberg, Sourcebook of Labor Markets: Evolving Structures and Processes, Springer Studies in Work and Industry

Margolis, David N., and Véronique Simonnet. 2003. Educational Track, Networks and Labor Market Outcomes, IZA DP 699.

Montgomery, James D. 1991. Social Networks and Labor-Market Outcomes: Toward an Economic Analysis, The American Economic Review 81/5: 1408-1418.

Montgomery, James D. 1992. Job Search and Network Composition: Implications of the Strength-Of-Weak-Ties Hypothesis, American Sociological Review 57/5: 586-596.

Montgomery, J. D. (1991). Social Networks an Labor-Market Outcomes: Toward an Economic Analysis, The American Economic Review, 81(5): 1408-1418.

Mouw, Ted. 2003. Social Capital and Finding a Job: Do Contacts Matter?, American Sociological Review 68/6: 868-898.

Mosca, Michele, and Francesco Pastore. 2009. Wage Effects of Recruitment Methods: The Case of the Italian Social Service Sector, Chapter 7 in Paid and Unpaid Labour in the Social Economy, AIEL Series in Labour Economics.

Niederle, Muriel, and Alexandra H. Yestrumskas. 2008. Gender Differences in Seeking Challenges: The Role of Institutions. NBER Working Paper 13922

Pellizzari, Michele. 2004. Do Friends and Relatives Really Help in Getting a Good Job? CEP Discussion Paper 623

Pistaferri, Luigi. 1999. Informal Networks in the Italian labor Market. Giornale degli Economisti 58/ 3-4: 355-375.

Ponzo, Michela, and Vincenzo Scoppa. 2008. The Use of Informal Networks in Italian Labor Markets: Effciency or Favoritisms?, MPRA DP 11764.

Rees, Albert. 1966. Information Networks in Labor Markets. American Economic Review 56 (1/2): 559-566.

Roshchin, Segey, and Ksenia Markova. 2004. Choice among Different Job Search Channels: The Evidence from Russian Labor Market, EERC WP Series.

Russo, Giovanni, Cees Gorter, Peter Nijkamp, and Piet Rietveld. 1997. Employers recruitment behavior: an empirical analysis of the role of personnel management attitudes. Labour 17/3: 599-623. 
Saloner, Garth. 1985. Old Boy Networks as Screening Mechanisms, Journal of Labor Economics 3/3: 255-267. 
Figure 1. Location of workers at city block level for Bogotá distinguish between job search channels
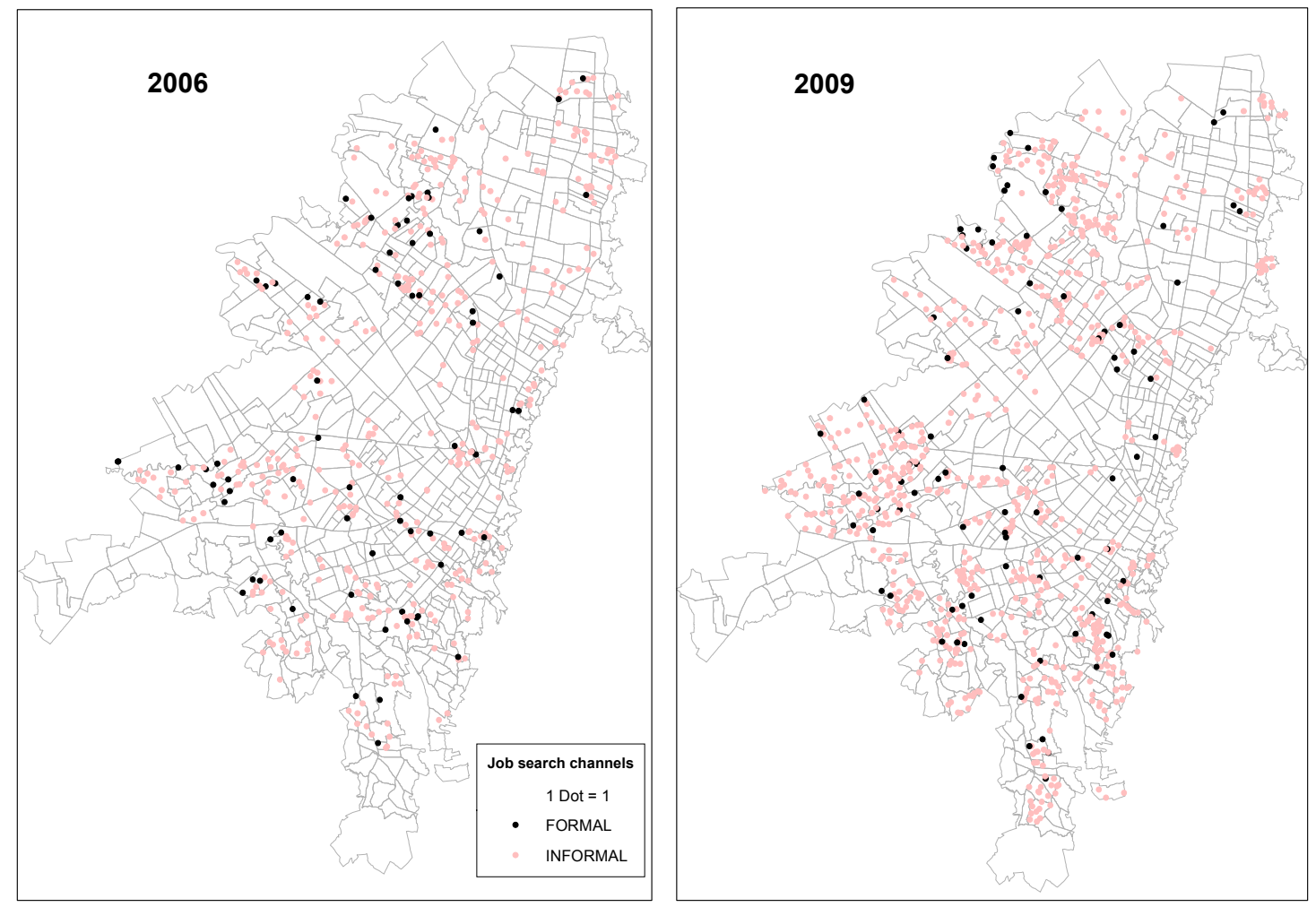
Table 1. Summary statistics

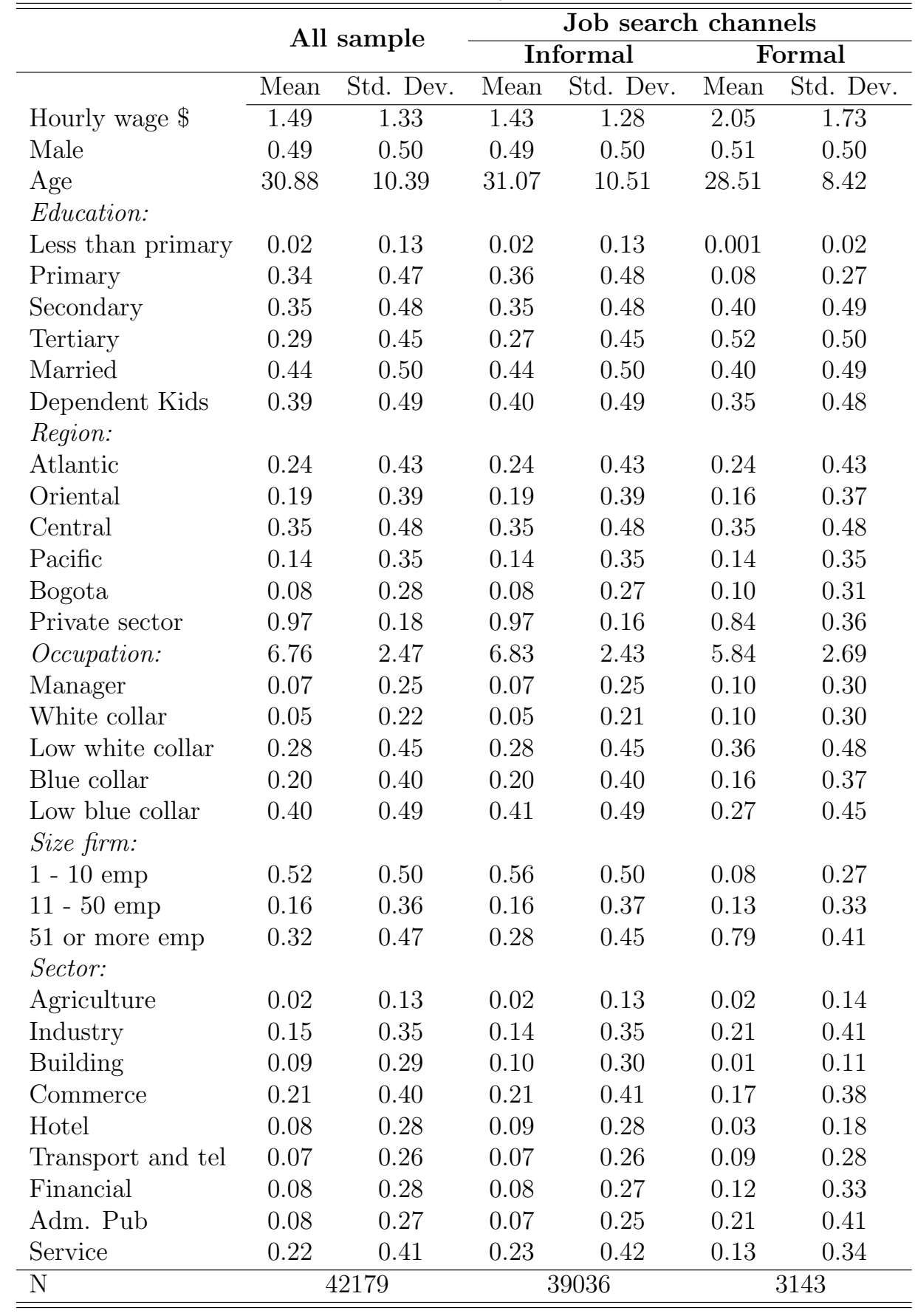


Table 2. Probability models

\begin{tabular}{lccc}
\hline \hline & M1 & M2 & M3 \\
\hline Neighborhood effects & $0.199^{* * *}$ & $0.094^{* * *}$ & $0.084^{* * *}$ \\
Age & $(0.014)$ & $(0.015)$ & $(0.015)$ \\
& 0.0001 & $-0.003^{* * *}$ & $-0.003^{* * *}$ \\
Education: & $(0.001)$ & $(0.001)$ & $(0.001)$ \\
Primary & & & \\
& $0.005^{* *}$ & $-0.005^{*}$ & $-0.006^{* *}$ \\
Secondary & $(0.003)$ & $(0.003)$ & $(0.003)$ \\
& $0.065^{* * *}$ & $0.019^{* * *}$ & $0.017^{* * *}$ \\
Tertiary & $(0.003)$ & $(0.003)$ & $(0.004)$ \\
& $0.111^{* * *}$ & $0.036^{* * *}$ & $0.036^{* * *}$ \\
Male & $(0.004)$ & $(0.005)$ & $(0.005)$ \\
& $0.015^{* * *}$ & -0.004 & -0.004 \\
Marital & $(0.003)$ & $(0.003)$ & $(0.003)$ \\
& 0.004 & -0.002 & -0.001 \\
Dependent kids & $(0.003)$ & $(0.003)$ & $(0.003)$ \\
& -0.005 & -0.004 & -0.003 \\
Private sector & $(0.005)$ & $(0.005)$ & $(0.005)$ \\
& & $-0.155^{* * *}$ & $-0.162^{* * *}$ \\
Constant & & $(0.013)$ & $(0.013)$ \\
& 0.006 & $0.226^{* * *}$ & $0.240^{* * *}$ \\
\hline N & $(0.011)$ & $(0.019)$ & $(0.019)$ \\
\hline Firm size dummies & 42179 & 42179 & 42179 \\
Occupation and industry dummies & $\mathrm{N}$ & $\mathrm{Y}$ & $\mathrm{Y}$ \\
City dummies & $\mathrm{N}$ & $\mathrm{Y}$ & $\mathrm{N}$ \\
\hline \hline Robust standard errors in parentheses. Less than primary education & $\mathrm{Y}$ as reference \\
for education & $* p<0.10, * * p<0.05, * * *$ & $p<0.01$ \\
& & &
\end{tabular}

Figure 2. Kernel density of log wage by formal and informal channel

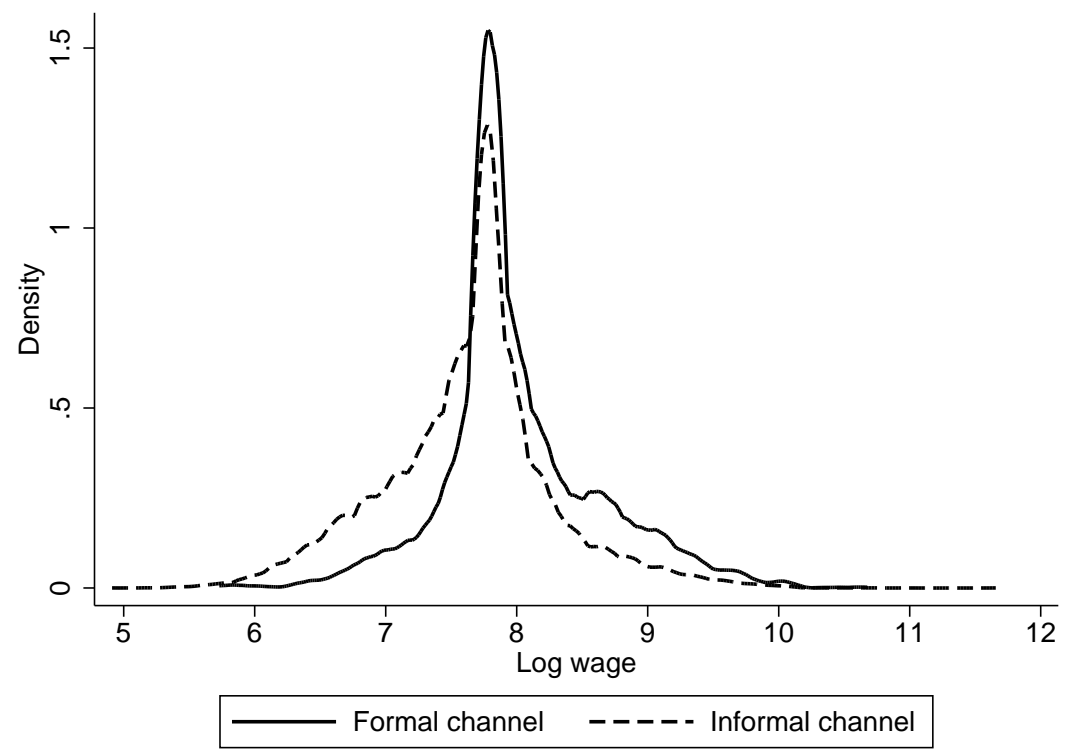


Table 3. Log Wage at different percentile

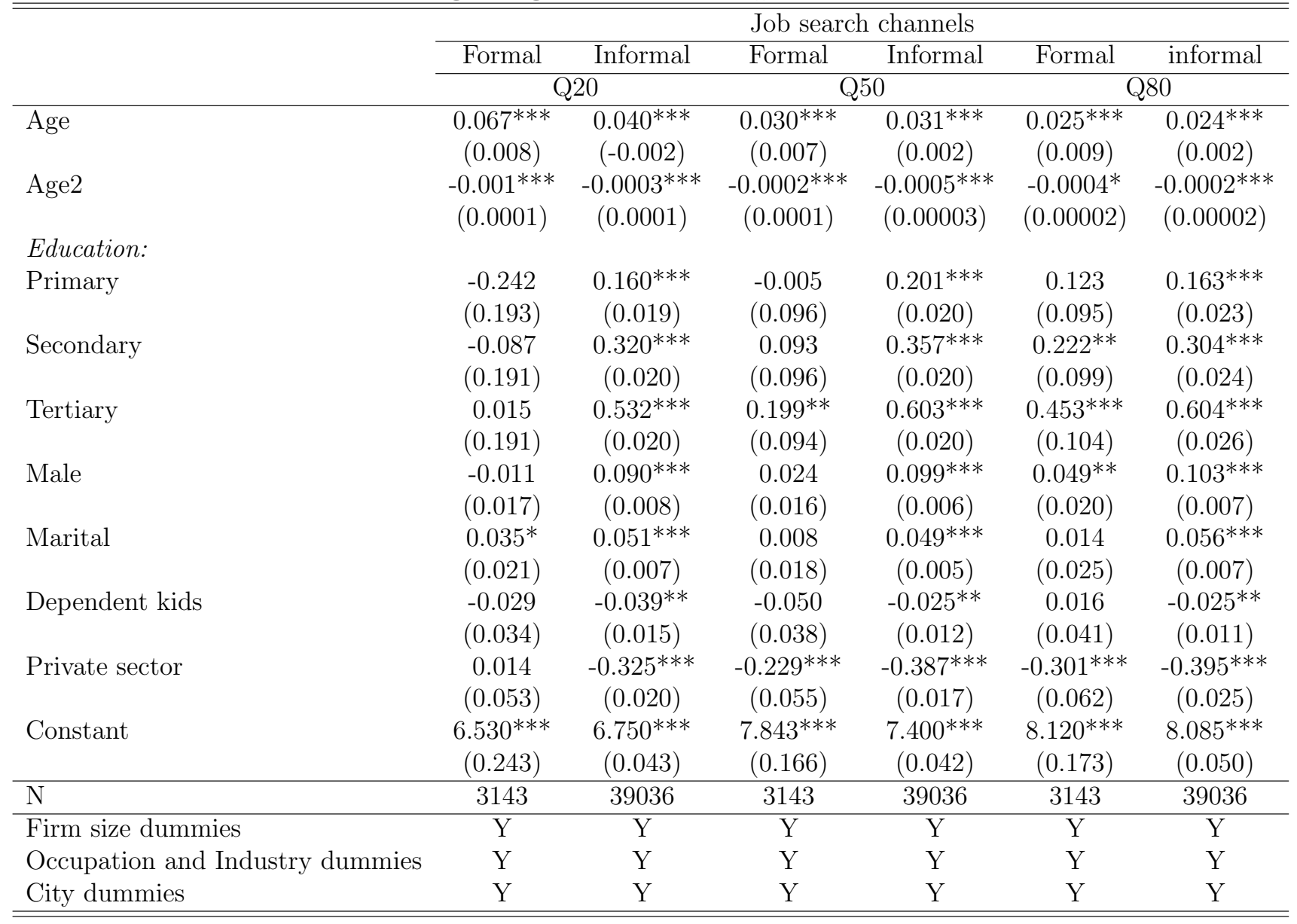

Robust standard errors in parentheses. Less than primary education as reference for education

${ }^{*} p<0.10,{ }^{* *} p<0.05,{ }^{* * *} p<0.01$

Figure 3. Quantile Decomposition

\section{Formal vs Informal}

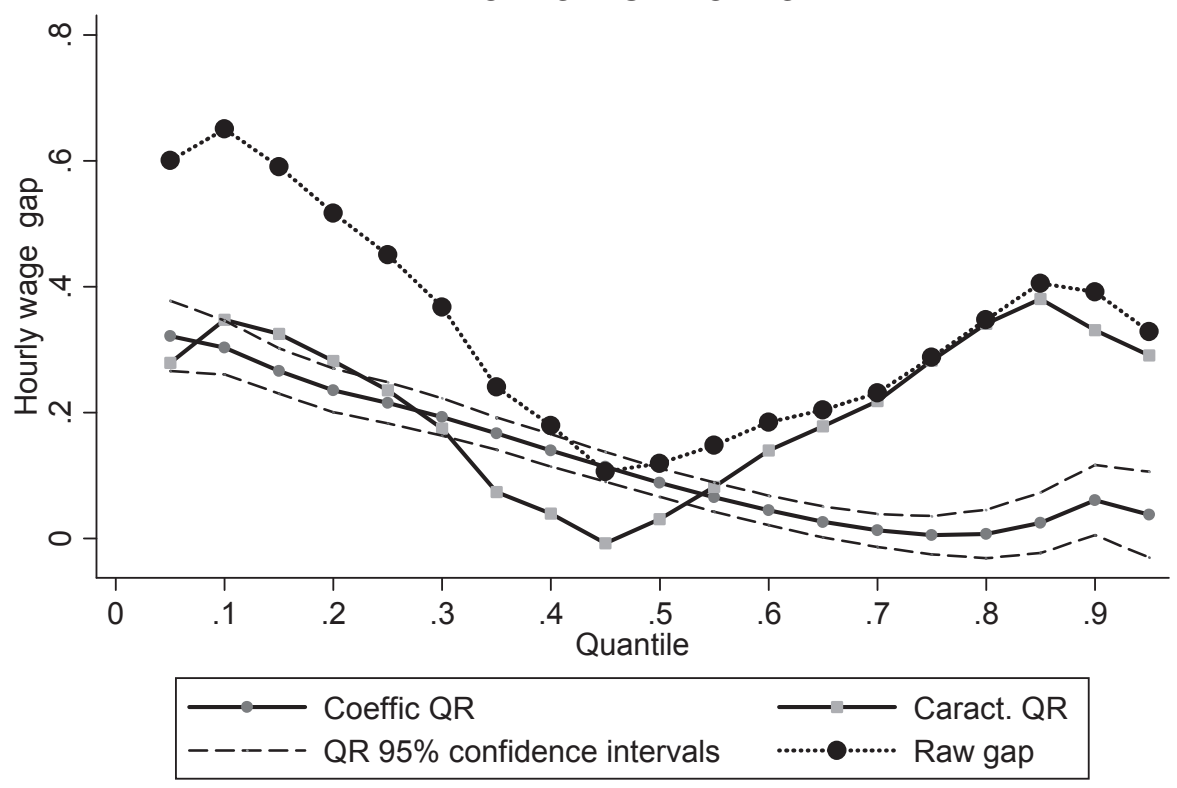

